Gut, 1980, 21, 299-304

\title{
Effect of a combination of gastrin, secretin, cholecystokinin, glucagon, and gastric inhibitory polypeptide on jejunal absorption in man
}

\author{
P POITRAS, R MODIGLIANI, AND J-J BERNIER
}

From the Hopital St Lazare, INSERM U-54, Puris, France

SUMMARY In 11 conscious volunteers, the jejunal absorption was measured during basal state and during the simultaneous intravenous infusion of small doses of gastrin, secretin, cholecystokinin, glucagon and gastric inhibitory polypeptide. The blood levels of gastrin, secretin, glucagon, and GIP were measured by RIA and were close to those achieved after a meal. The basal net absorption of water and electrolytes was reversed to a net secretion during the hormonal infusion. These results suggest that the jejunal secretion observed after a meal in man may be mediated by hormones released by the meal.

Many reports have demonstrated that gastrointestinal (GI) hormones can decrease the absorption, or induce the secretion, of water and electrolytes by the human small intestine. ${ }^{1}$ However, the physiological meaning of such findings is doubtful, as most of the studies were done with pharmacological doses of a single hormone. The aim of this work is to determine whether a simultaneous infusion of small doses of gastrin, secretin, cholecystokinin (CCK), glucagon and gastric inhibitory polypeptide (GIP), in an attempt to simulate the normal postprandial gastrointestinal hormone release, influences human jejunal absorption.

\section{Methods}

INTESTINAL PERFUSION STUDIES

Studies were performed after an overnight fast on nine male and two female subjects, aged from 18 to 45 years, who were free of gastrointestinal disease. Movements of water and electrolytes were measured by the technique of intestinal perfusion with a triple lumen catheter. ${ }^{2}$ The mixing and the test segments were $15 \mathrm{~cm}$ and $25 \mathrm{~cm}$ long respectively. The distal mercury bag which weighed the tube down was attached at the tip of a blind-ended fourth tube (Fig. 1). The latter was bound to the triple lumen catheter in such a way that it could be separated from it when the infusion point had reached the desired position, in order to prevent further pro-

Received for publication 28 October 1979 gression of the tube over the two-day experiment. The infusion tip was positioned fluoroscopically just beyond the ligament of Treitz. Solutions were then infused at this site during a 60 minute equilibration period followed by four 30 minute sampling periods. Proximal samples were recovered by aspiration with a calibrated syringe at the constant rate of $1 \mathrm{ml} / \mathrm{min}$; distal sampling was made by simple siphonage and was delayed by 10 minutes to allow for the transit time of the fluid through the test segment. ${ }^{3}$

On the first day, the five hormones, diluted in isotonic saline and mixed in the same syringe, were given by intravenous infusion at the following doses: synthetic human gastrin 1 heptadecapeptide 28.6 pmol $(0.06 \mu \mathrm{g}) / \mathrm{kg} / \mathrm{h}$, GIH secretin $8.2 \mathrm{pmol}(0.1$ $\mathrm{CU} / \mathrm{kg} / \mathrm{h}, 95 \%$ pure cholecystokinin (GIH CCK) $21.25 \mathrm{pmol}(0.25$ Ivy dogs Unit $) / \mathrm{kg} / \mathrm{h}$, glucagon Novo $17.2 \mathrm{pmol}(0.06 \mu \mathrm{g}) / \mathrm{kg} / \mathrm{h}$, GIP $117.5 \mathrm{pmol}$ $(0.6 \mu \mathrm{g}) / \mathrm{kg} / \mathrm{h}$. The infusate was administered at a rate of $0.6 \mathrm{ml} / \mathrm{min}$ with a Braun-Melsunger pump. The test solution was perfused with a Technicon pump into the intestine at a rate of $8 \mathrm{ml} / \mathrm{min}$ and contained $\mathrm{Na}^{+} 145 \mathrm{mmol} / \mathrm{l}, \mathrm{K}^{+} 5 \mathrm{mmol} / \mathrm{l}, \mathrm{Cl}^{-} 150$ $\mathrm{mmol} / \mathrm{l}$, and PEG $40003 \mathrm{mmol}(10 \mathrm{~g}) / \mathrm{l}$. The flow rate and composition of fluid entering the test segment was determined on the same day by measuring the concentration of PEG in the test solution and that of PEG and ions in the proximal samples.

On the second day, isotonic saline was infused intravenously. The rate of perfusion and the electrolyte concentration of the intestinal test solution were 


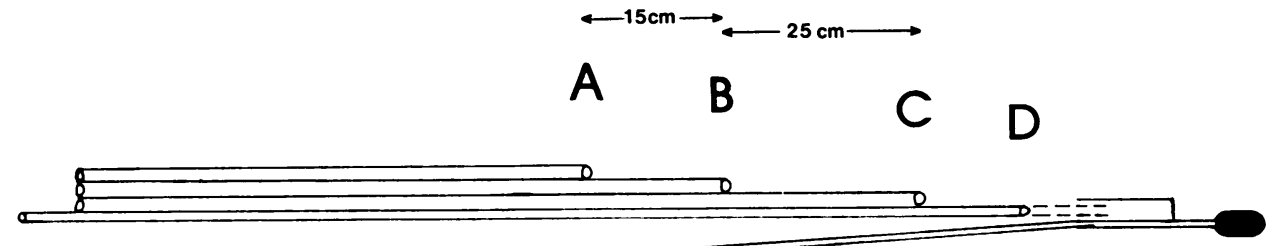

Fig. 1 Perfusion tube. A: perfusion tip; A-B: mixing segment; $B$-C: test segment; $D$ : separation point. Before being introduced through the nose, the triple lumen catheter is glued to a fourth tube with its distal tip inserted tightly into a bigger tube. This last tube is glued to another small catheter carrying the mercury bag. Once in place in the intestine, a bolus of water, or air, injected by a syringe in the fourth tube easily separates the two units.

adjusted so that, in each subject, the flow rate and ions concentration at the entry of the test segment were similar to those prevailing at this site the day before. Table 1 shows that this was correctly achieved, except for a significantly higher bile salt concentration on the first day $(\mathbf{P}<0.001)$.

\section{BLOOD SAMPLING}

Venous blood was obtained during basal periods $(-15 \mathrm{~min}, 0 \mathrm{~min})$ and after $60,90,120,150,180$ minutes of hormone infusion. Blood was collected on ice into heparinised tubes with addition of 400 $\mathrm{IKU} / \mathrm{ml}$ of aprotinin. Plasma was immediately separated by centrifugation and stored at $-80^{\circ} \mathrm{C}$ until assay.

Human synthetic gastrin 1 heptadecapeptide was graciously given by J C Morley, Imperial Chemical Industries, England; secretin and $95 \%$ pure CCK were purchased from the GIH Research Institute, Karolinska, Sweden; glucagon was purchased from Novo Products, Paris, France; and GIP was purchased from Dr J C Brown, University of British Columbia, Vancouver, Canada.

\section{ANALYTICAL METHODS}

Sodium and potassium were measured by flame photometry; chloride and bicarbonates were analysed on a Technicon Auto-Analyser; PEG was determined in duplicate by the method of Hyden ${ }^{4}$ and bile salts were measured according to Iwata. ${ }^{5}$ Radioimmunoassays of serum gastrin, secretin, glucagon, and GIP were performed respectively by J P Accary ${ }^{6}$ (Unite de Recherche de Gastro-
Enterolgie, U. 10 INSERM, Hopital Bichat, Paris, France), W. Chey ${ }^{7}$ (Department of Medicine, the Genesee Hospital, Rochester, New York, USA), R Assan ${ }^{8}$ (Hotel Dieu, Paris, France), and J C Brown $^{9}$ (Department of Physiology, University of British Columbia, Vancouver, Canada).

\section{CALCULATIONS AND EXPRESSION}

OF RESULTS

Net movements of water and electrolytes across the intestine were calculated from the measured concentrations of PEG and solutes in proximal and distal aspirations using the standard formulas. ${ }^{2}$ The term net absorption (- sign) refers to disappearance of water and electrolytes from the lumen and net secretion (+ sign) refers to gain of water and electrolytes into the lumen. All data are expressed as mean \pm SEM. Statistical analysis of results was performed using Student's $t$ test.

\section{Results}

Hormonal levels: The blood levels, as measured by radioimmunoassay, achieved during infusion of the hormone mixture are shown in Table 2.

Water and electrolytes: The basal net absorption of water, sodium, and chloride was reversed to a net secretion during hormonal infusion $(\mathrm{P}<0.01)$. The same type of phenomenon also occurred for potassium and bicarbonates but failed to reach statistical significance (Table 3). As shown in Fig. 2, a net secretory effect was elicited in eight of the 11 subjects tested.

Table 1 Rate of fluid and concentrations of ions at entry of test segment on each day of experiment

\begin{tabular}{|c|c|c|c|c|c|c|}
\hline & $\begin{array}{l}\text { Rate of fluid } \\
(\mathrm{ml} / \mathrm{min})\end{array}$ & $\begin{array}{l}\mathrm{Na} \\
(\mathrm{mmol} / \mathrm{l})\end{array}$ & $\begin{array}{l}K \\
(\mathrm{mmol} / \mathrm{l})\end{array}$ & $\begin{array}{l}\mathrm{Cl} \\
(\mathrm{mmol} / l)\end{array}$ & $\begin{array}{l}\mathrm{HCO}_{\mathbf{3}} \\
(\mathrm{mmol} / \mathrm{l})\end{array}$ & $\begin{array}{c}\text { Bile salts } \\
(\mathrm{mmol} / \mathrm{l})\end{array}$ \\
\hline $\begin{array}{l}\text { Hormones } \\
\text { Basal } \\
\mathbf{P}\end{array}$ & $\begin{array}{l}9.55 \pm 0.30 \\
10.06 \pm 0.40 \\
>0.30\end{array}$ & $\begin{array}{l}140 \cdot 1 \pm 0.7 \\
138 \cdot 8 \pm 1 \cdot 2 \\
>0.40\end{array}$ & $\begin{array}{l}5 \cdot 5 \pm 0 \cdot 8 \\
5 \cdot 6 \pm 0 \cdot 8 \\
>0.70\end{array}$ & $\begin{array}{l}142 \cdot 2 \pm 0.9 \\
140 \cdot 8 \pm 1 \cdot 2 \\
>0.30\end{array}$ & $\begin{array}{l}3 \cdot 2 \pm 0.4 \\
3.03 \pm 0.4 \\
>0.60\end{array}$ & $\begin{array}{l}2.49 \pm 0.19 \\
0.73 \pm 0.13 \\
<0.0001\end{array}$ \\
\hline
\end{tabular}


Table 2 Concentrations of plasma hormones on first day of experiment

\begin{tabular}{|c|c|c|c|c|c|c|c|c|}
\hline & \multicolumn{7}{|c|}{ Blood levels measured by RIA (pg/ml) } & \multirow{2}{*}{$\begin{array}{l}\text { Postprandial increase } \\
\text { observed in each } \\
\text { laboratory involved } \\
(p g / m l)\end{array}$} \\
\hline & $\underset{-15}{\text { Time }}(\min ):$ & 0 & 60 & 90 & 120 & 150 & 180 & \\
\hline Gastrin & $42 \pm 15$ & $57 \pm 20$ & $202 \pm 41$ & $245 \pm 40$ & $245 \pm 35$ & $252 \pm 28$ & & $\begin{array}{l}3 \text { times increase over } \\
\text { basal value }\end{array}$ \\
\hline $\begin{array}{l}\text { Secretin } \\
\text { GIP } \\
\text { Glucagon }\end{array}$ & $\begin{array}{c}6 \pm 2 \cdot 8 \\
483 \pm 99 \\
98 \pm 12\end{array}$ & $\begin{array}{l}537 \pm 111 \\
101 \pm 12\end{array}$ & $\begin{array}{l}21 \cdot 2 \pm 3 \cdot 9 \\
463 \pm 83 \\
107 \pm 12\end{array}$ & $\begin{array}{l}18 \cdot 8 \pm 4 \cdot 0 \\
611 \pm 119 \\
104 \pm 18\end{array}$ & $\begin{array}{l}20 \cdot 4 \pm 3 \cdot 7 \\
746 \pm 163 \\
119 \pm 20\end{array}$ & $\begin{array}{l}19 \cdot 2 \pm 3 \cdot 4 \\
880 \pm 207 \\
110 \pm 16\end{array}$ & $\begin{array}{c}20 \cdot 9 \pm 3 \cdot 2 \\
1056 \pm 199 \\
109 \pm 13\end{array}$ & $\begin{array}{l}\text { Range from }<10 \text { to } 20 \\
1200 \pm 200 \\
100-150\end{array}$ \\
\hline
\end{tabular}

Table 3 Net movements of water and electrolytes across jejunal wall during saline or hormonal mixture perfusion

\begin{tabular}{llllll}
\hline & $\mathrm{H}_{2} \mathrm{O}$ & $\mathrm{Na}$ & $\mathrm{Cl}$ & $K$ & $\mathrm{HCO}$, \\
\hline Basal & $-0.43 \pm 0.1$ & $-62.6 \pm 13.6$ & $-68.32 \pm 13.54$ & $-2.30 \pm 0.95$ & $+3.37 \pm 3.78$ \\
Hormones & $+0.32 \pm 0.19$ & $+37.62 \pm 27.1$ & $+29.02 \pm 26.56$ & $+1 \cdot 71 \pm 1.57$ & $+11.39 \pm 3.35$ \\
P & $<0.01$ & $<0.01$ & $<0.01$ & $<0.10$ & $<0.20$ \\
\hline
\end{tabular}

Negative sign denotes absorption: positive sign denotes secretion.

Values are expressed in $\mathrm{ml}$ or $\mu \mathrm{mol} / \mathrm{min} / 25 \mathrm{~cm}$.

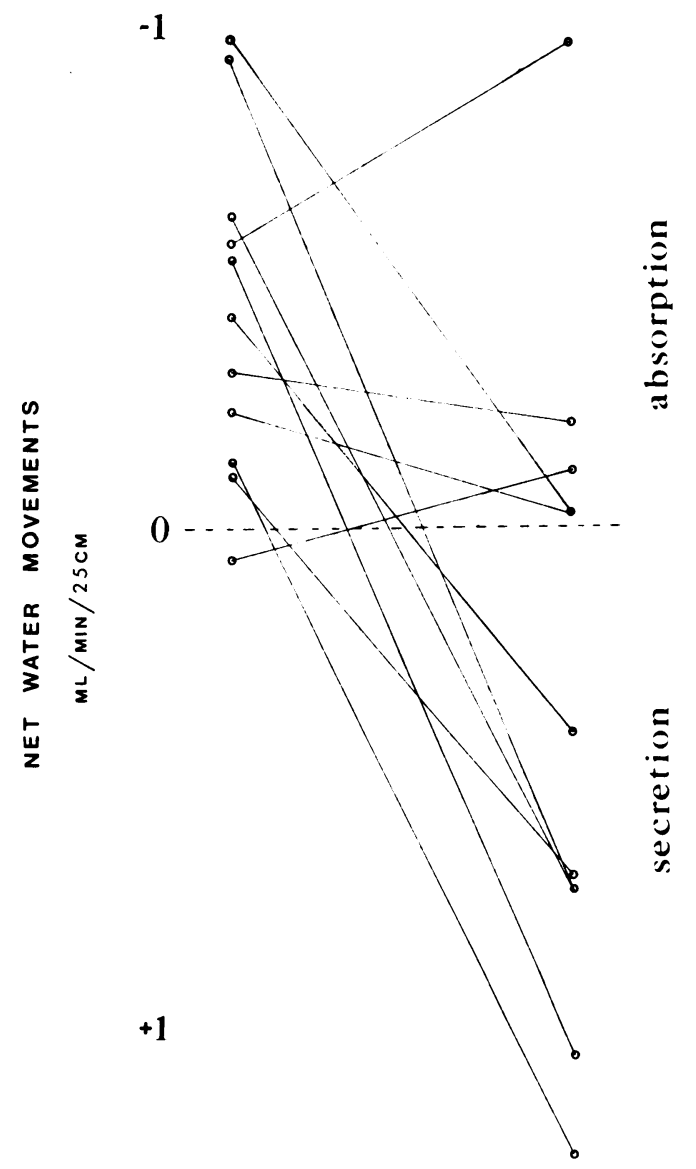

BASAL HORMONES

Fig. 2 Absorption of water during the basal period and during the infusion of peptides.

\section{Discussion}

The present results show that a simultaneous infusion of small doses of gastrin, secretin, CCK, glucagon, and GIP induces a secretion of water and electrolytes by the human jejunum.

The rates of basal absorption obtained in our experiment are lower than those found in other studies using similar solutions and rates of perfusion. ${ }^{310}$ This is probably because the catheter was not attached to a mercury bag. It is well known that this mercury bag, by pulling the tube down, increases the real length of the test segment. ${ }^{11}$ This difference does not invalidate our results; indeed, the secretion observed would have been probably greater with a standard tube.

Gastrin, CCK, secretin, glucagon, and GIP have all been shown, when infused alone, to decrease the absorption, or induce a secretion, of water and electrolytes by the human small intestine. ${ }^{1}$ Most of these studies, however, have used supraphysiological amounts of hormone; the lowest reported doses able to reduce significantly the fluid absorption in man are $0.5 \mu \mathrm{g} / \mathrm{kg} / \mathrm{h}$ of synthetic human gastrin, ${ }^{12}$ $1 \mathrm{Ivy} \operatorname{dog} \mathrm{U} / \mathrm{kg} / \mathrm{h}$ of CCK, ${ }^{13} 1 \mathrm{CU} / \mathrm{kg} / \mathrm{h}$ of secretin, ${ }^{13}$ $0.6 \mu \mathrm{g} / \mathrm{kg} / \mathrm{h}$ of glucagon,,$^{14}$ and $1 \mu \mathrm{g} / \mathrm{min}$ of GIP..$^{15}$

The physiological doses of many gastrointestinal hormones are still not well known. In the present study, in attempting to simulate the postprandial release of gastrointestinal hormones, the doses of hormones were chosen so as to (1) be smaller than those required to elicit a half-maximal response $\left(D_{50}\right)$ on the main target organ; (2) give circulating levels in the range of those observed after a meal. The dose of synthetic gastrin used $(28.6 \mathrm{pmol} / \mathrm{kg} / \mathrm{h}$ represents one-third of the $D_{50}$ of this hormone for gastric secretion ${ }^{12}$ and has been shown to give a 
serum gastrin concentration similar to that produced by feeding. ${ }^{16}$ The levels of circulating gastrin measured in the present study are slightly higher than those usually observed after a meal (Accary, personal communication). However, in five of our subjects, gastric acid secretion measured during the infusion of gastrin alone was found to be in a physiological range $(13.37 \pm 2.35 \mathrm{mmol} / \mathrm{h})$. Moreover, gastrin alone is probably not responsible for the jejunal secretion observed here, as we have previously shown that an infusion of $59.6 \mathrm{pmol} / \mathrm{kg} / \mathrm{h}$ was unable to reduce significantly the fluid absorption in the human jejunum. ${ }^{12}$ The dose of CCK that we have infused $(21.25 \mathrm{pmol} / \mathrm{kg} / \mathrm{h})$ is less than the $D_{50}$ for the secretion of pancreatic enzymes, as can be deduced from the studies of Malagelada et al. ${ }^{17} 18$ The CCK blood levels could not be measured; however, bearing in mind that the duodenal bile salts increase as an indirect index of CCK activity, the secretion of bile salts elicited by the intravenous hormonal infusion was not greater than that obtained with a jejunal amino acid perfusion. ${ }^{19}$ The amount of secretin released postprandially has been indirectly estimated at $0.5 \mathrm{CU} / \mathrm{kg} / \mathrm{h} .{ }^{20}$ In fact, there is some controversy as to whether secretin is released by a meal, because of the failure of several immunoassays to detect any postprandial increase in the blood level of this hormone. ${ }^{2122}$ However, a small rise in immunoreactive secretin after feeding has been found by other authors. ${ }^{73}$ Thus, we infused a very small dose of this hormone $(8 \cdot 2 \mathrm{pmol} /$ $\mathrm{kg} / \mathrm{h}$ ), which induced a rise in circulating secretin comparable with that measured by Chey after a meal (Chey, personal communication). The dose of glucagon used is considered as physiological ${ }^{24}$ and induced a very small rise in the level of immunoreactive glucagon, similar to that observed after a meal. ${ }^{25} 26$ The amount of GIP we used is considered as physiological. ${ }^{27}$ For some unknown reason, however, we did not obtain a steady level of circulating GIP, but the highest values measured are within the range of normal postprandial values. ${ }^{9}$

It can thus be assumed that the amounts of the five hormones infused here are not far from those released by a normal meal. Yet, the simulation of the postprandial condition obtained in this work is still imperfect, as (1) the hormones were infused in a peripheral vein and not in the portal system; (2) the molecular form of the substance given was probably different from the circulating hormone (vg:gastrin 17 was infused alone instead of a mixture of all gastrin components; (3) porcine peptides were infused, as the structure of some human hormones is still unknown; (4) all possible released peptides have not been used. Indeed, a clear rise of pancreatic polypeptide was documented to occur after a meal ${ }^{28}{ }^{28}$; this peptide was not included because it was not available for human infusion when this work was done. Vasointestinal polypeptide, motilin, and somatostatin were not given because their postprandial release is still disputed..$^{30-33}$

The present study was not designed to investigate the mechanism of the secretory effect of the hormones infused. The adenylate cyclase system is probably not involved, as none of the five peptides we have used was shown to stimulate this system in the small intestine. ${ }^{34}$ As a result of the CCK infusion, the total concentrations of bile salts was higher during the hormonal infusion than in the basal period and dihydroxy bile salts are known to induce a jejunal secretion of fluid in man. ${ }^{35}{ }^{36}$ But this mechanism is probably not responsible for the secretion we observed, as (1), in our experiment, the quantity of dihydroxy bile salts in the jejunum is probably lower than the concentration usually required $(2-3 \mathrm{mmol} / \mathrm{l})$ to induce a secretion ${ }^{36}{ }^{36}$; indeed, the total concentration of bile salts in the test segment was $2 \cdot 49 \pm 0.19 \mathrm{mmol} / 1$ and the dihydroxylate salts represent only $60 \%$ of the total bile salts $^{37} ;$ (2) the normal bile released in our experiment contains lecithin, which was shown to abolish the secretory effect induced by the biliary salts on the human intestine ${ }^{35}$ However, the effects of bile salts and hormones could be additive.

After a meal, the volume of the intestinal content progressively decreases from duodenum to caecum..$^{38}$ However, recently, Wright et al ${ }^{39}$ showed in experimental conditions in man that a jejunal secretion of water and electrolytes occurred when a nutrient mixture was perfused in the duodenum. The cause of this secretion was not elucidated, however. More than 40 years ago, Nasset et al. ${ }^{40}$ observed a postprandial secretion of fluid in denervated Thiry-Vella loops of canine jejunum and suggested the existence of a humoral substance released by a meal and responsible for this secretion. Our study demonstrates that an intravenous infusion of five gastrointestinal hormones known, or suggested, to be released by a meal induces in man a jejunal secretion of water and electrolytes. Each hormone was infused at levels close to those achieved after a meal. Our work supports Nasset's hypothesis that humoral substances may be involved in the postprandial jejunal secretion. Additional studies are required to evaluate which peptide, or which combination of peptides, induced this secretion.

\section{References}

${ }^{1}$ Modigliani R, Bernier JJ, Matuchansky C, Rambaud JC. Intestinal water and electrolyte transport in man under the effect of exogenous hormones of the gut and 
prostaglandins and in patients with endocrine tumors of the pancreas. In: Glass GB, ed. Progress in gastroenterology. New York: Grune and Stratton, 1977: 3: 285-319.

${ }^{2}$ Modigliani R, Rambaud JC, Bernier JJ. The method of intraluminal perfusion of the human small intestine. I: Principle and technique. Digestion 1973; 9: 176-92.

${ }^{3}$ Whalen GE, Harris JA, Geenen JE, Soergel KH. Sodium and water absorption from the human small intestine. The accuracy of the perfusion method. Gastroenterology 1966; 51 : 975-84.

${ }^{4}$ Hydén S. A turbidimetric method for the determination of higher polyethylene glycols in biological materials. K Lantbrtlögski Annlr 1956; 22: 139-45.

${ }^{5}$ Iwata T, Yamasaki K. Enzymatic determination and thin layer chromatography of bile acids in blood. J Biochem Tokyo 1964; 56: 424-31.

${ }^{6}$ Accary JP, Bonfils S. Le dosage radioimmunologique de la gastrine. Biol Gastroenterol (Paris) 1971; 1: 79-91

${ }^{7}$ Chey WY, Hendricks J, Tai HH. Plasma secretin in fasting and postprandial state in man. (Abstract). Gastroenterology 1977; 72: 1156.

${ }^{8}$ Assan R, Tchobroutsky G, Derot M. Glucagon radioimmunoassay: technical problems and recent data. Horm and Met Research 1971 ; 3 (Suppl. 3): 82-90.

${ }^{9}$ Kuzio M, Dryburgh JR, Malloy KM, Brown JC. Radioimmunoassay for gastric inhibitory polypeptide. Gastroenterology 1974; 66: 357-64.

${ }^{10}$ Modigliani R, Mary JY, Bernier JJ. Effect of pentagastrin upon movements of water, electrolytes and glucose across the human jejunum and ileum. Digestion 1973; 8: 208-19.

${ }^{11}$ Cook GC, Carruthers RH. Reaction of human small intestine to an intraluminal tube and its importance in jejunal perfusion studies. Gut 1974; 15: 545-8.

${ }^{12}$ Modigliani R, Mary JY, Bernier JJ. Effect of synthetic human gastrin I on movements of water, electrolytes, and glucose across the human small intestine. Gastroenterology 1976; 71 : 978-84.

${ }^{13}$ Moritz M, Finkelstein G, Meshkinpour H, Fingerut J, Lorber SH. Effect of secretin and cholecystokinin on the transport of electrolyte and water in human jejunum. Gastroenterology 1973; 64: 76-80.

${ }^{14}$ Hicks T, Turnberg LA. Influence of glucagon on the human jejunum. Gastroenterology 1974; 67: 1114-8

${ }^{15}$ Helman CA, Barbezat Go. The effect of gastric inhibitory polypeptide on human jejunal water and electrolyte transport. Gastroenterology 1977; 72: 376-9.

${ }^{16}$ Freeland GR, Higgs RH, Castell DO, McGuigan JE. Lower oesophageal sphincter and gastric acid responses to intravenous infusions of synthetic human gastrin 1 heptadecapeptide. Gastroenterology 1976; 71: 570-4

${ }^{17}$ Malagelada JR, Go VLW, Summerskill WHJ. Differing sensitivities of gallbladder and pancreas to cholecystokinin-pancreozymin (CCK-PZ) in man. Gastroenterology 1973; 64: 950-4.

${ }^{18}$ Malagelada JR, Go VLW, Summerskill WHJ. Altered pancreatic and biliary function after vagotomy and pyloroplasty. Gastroenterology 1974; 66: 22-7.

${ }^{19}$ Ertan A, Brooks FP, Ostrow JD, Arvan DA, Williams $\mathrm{CN}$, Cerda JJ. Effect of jejunal amino acid perfusion and exogenous cholecystokinin on the exocrine pan- creatic and biliary secretions in man. Gastroenterology $1971 ; 61$ : 686-92.

${ }^{20}$ Meyer JH, Way LW, Grossman MI. Pancreatic response to acidification of various lengths of proximal intestine in the dog. Am J Physiol 1970; 219: 971-7.

${ }^{21}$ Boden G, Wilson RM, Essa-Koumar N, Owen OE. Effects of a protein meal, intraduodenal $\mathrm{HCl}$, and oleic acid on portal and peripheral venous secretin and on pancreatic bicarbonate secretion. Gut 1978; 19: 277-83.

${ }^{22}$ Kolts BE, McGuigan JE. Radioimmunoassay measurement of secretin half-life in man. Gastroenterology 1977; 72: 55-60.

${ }^{23}$ Straus E, Yalow RS. Hypersecretinemia associated with marked basal hyperchlorhydria in man and dog. Gastroenterology 1977; 72: 992-4.

${ }^{24}$ Alford FP, Bloom SR, Nabarro JDN, Hall R, Besser $\mathrm{GM}$, Coy $\mathrm{DH}$, et al. Glucagon control of fasting glucose in man. Lancet 1974; 2: 974-7.

${ }^{25}$ Lefebvre PJ, Luyck AS. The breakfast tolerance test: a return to physiology. Diabete Metab 1976; 2 (1): 15-9.

${ }^{26}$ Gerich JE, Lorenzi M, Karam JH, Schneider V, Forsham PH. Abnormal pancreatic glucagon secretion and postprandial hyperglycemia in diabetes mellitus. J Am Med Assoc 1975; 234: 159-65.

${ }^{27}$ Dupre J, Ross SA, Watson D, Brown JC. Stimulation of insulin secretin by gastric inhibitory polypeptide in man. $J$ Clin Endocrinol Metab 1973; 37: 826-8.

${ }^{28}$ Floyd JC Jr, Fajans SS, Pek S. Physiologic regulation of plasma levels of PP in man. In: Bloom SR, ed. Gut hormones. Edinburgh: Churchill Livingstone, 1978: 247-53.

${ }^{29}$ Adrian TE, Bloom SR, Besterman HS, Bryant MG. PP_physiology and pathology. In: Bloom SR, ed. Gut hormones Edinburgh and London: Churchill Livingstone, 1978: 254-60.

${ }^{30} \mathrm{O}$ 'Dorisio TM. Pathophysiology of VIP II. In: Bloom SR, ed. Gut hormones. Edinburgh and London: Churchill Livingstone, 1978: 484-7.

${ }^{31}$ Mitznegg P, Bloom SR, Christofides N, et al. Release of motilin in man. Scand J Gastroenterol 1976; 11 (suppl 39): 53-56.

${ }^{32}$ Becker HD, Arnold R, Börger HW, Schafmayer A, Werner M. Studies on motilin release in man. (Abstract). Gastroenterology 1978; 74: 1007.

${ }^{33}$ Arimura A, Coy DH, Chihara M, et al. Somatostatin. In: Bloom SR, ed. Gut hormones. Edinburgh and London: Churchill Livingstone, 1978: 437-45.

${ }^{34}$ Klaevemen HL, Conlon TP, Levy AG, Gardner JD. Effects of gastrointestinal hormones on adenylate cyclase activity in human jejunal mucosa. Gastroenterology 1975; 68: 667-75.

${ }^{35}$ Wingate DL, Phillips SF, Hofmann AF. Effect of glycine-conjugated bile acids with and without lecithin on water and glucose absorption in perfused human jejunum. J Clin Invest 1973; 52: 1230-6.

${ }^{36}$ Russell RI, Allan JG, Gerskowitch VP, Cochran CM. The effect of conjugated and unconjugated bile acids on water and electrolyte absorption in the human jejunum Clin Sci and Mol Med 1973; 45: 301-11.

${ }^{37}$ LaRusso NF, Szcsepanik PA, Hofmann AF. Effect of 
deoxycholic acid ingestion on bile acid metabolism and biliary lipid secretion in normal subjects. Gastroentero$\log y$ 1977; 72: 132-40.

${ }^{38}$ Fordtran JS, Locklear TW. Ionic constituents and osmolality of gastric and small-intestinal fluids after eating. Am J Dig Dis 1966; 11: 503-21.
${ }^{39}$ Wright JP, Barbezat GO, Clain JE. Jejunal secretion in response to a duodenal mixed nutrient perfusion. Gastroenterology 1979; 76: 94-8.

${ }^{40}$ Nasset ES, Pierce HB, MNurlin JR. Proof of a humoral control of intestinal secretion. Am J Physiol 1935; 3: 145-58. 